\title{
NUTRITIONAL CONSTRAINTS TO LEAN TISSUE ACCRETION IN FARM ANIMALS
}

\author{
R. G. CAMPBELL \\ Animal Research Institute, Werribee, Victoria 3030, Australia
}

\section{CONTENTS}

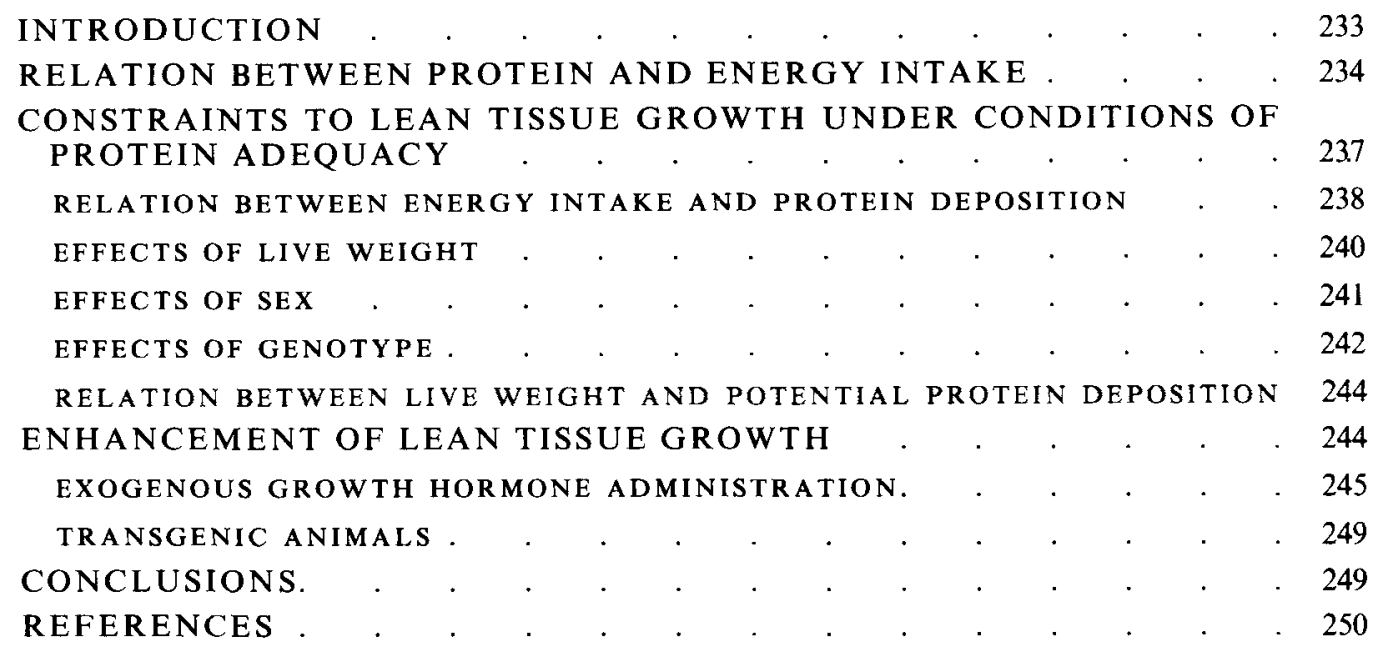

\section{INTRODUCTION}

During the last decade the emphasis in animal production has switched from promoting maximum or near maximum growth to altering the efficiency and composition of growth, and the enhancement of lean tissue growth or protein accretion.

These changes have been brought about by increasing consumer demand for leaner meat products, and the realization that at the same level of feed or energy intake enhancement of lean tissue growth is associated with improvements in the rate and efficiency of liveweight gain, and with reduced lipogenesis and carcass fatness.

The extent to which lean tissue growth is influenced by nutrition is reasonably-well established. The basic principles determining the response of lean tissue growth to change in nutrient intake also appear to be qualitively the same for most domestic animal and avian species. Nevertheless, animal species differ in their capacity for lean tissue growth and some are more limited by nutrition than others. Because of their inherently-low appetite ruminant species probably never consume sufficient energy to express fully their genetic potential for lean tissue growth. On the other hand, the appetite of growing pigs may exceed their inherent capacity for lean tissue growth, and energy intake often has to be restricted to prevent excessive fat development.

Even within a species the capacity of the growing animal for lean tissue growth is influenced by factors such as live weight, sex and breed or genotype, and any discussion of lean tissue growth would be incomplete unless the interrelationships between nutrient 
intake and these other factors were considered. This is particularly pertinent when considering nutritional constraints to lean tissue growth, because while the same intake of a particular nutrient may enable full expression of one animal's capacity for lean tissue growth it may seriously constrain that of another of higher lean tissue growth potential.

The large differences in lean tissue growth potential known to exist between breeds (Moody et al. 1978; Butterfield et al. 1983) and between sexes and strains within a breed (Campbell et al. 1985b; Campbell \& Taverner, 1985) also serve to illustrate the extent to which lean tissue growth can be constrained by intrinsic rather than nutritional factors.

Indeed, future improvement in the efficiency of meat production and the ability of the animal industries to keep pace with rapidly-changing consumer demands may be largely dependent on identifying and ultimately removing these intrinsic constraints to lean tissue growth. The possibility of success in this area has been increased by recent developments in the field of biotechnology which have provided animal scientists with previouslyunavailable materials and techniques to probe the metabolic and biochemical controls of growth and development. In the final sections of the present review, the potential, and biological and practical implications of two of these relatively-new technologies (exogenous growth-hormone $(\mathrm{GH})$ administration and gene incorporation) are discussed.

In the initial sections of the paper attention has been concentrated on the interrelationships between nutrient intake and various animal factors on the capacity of the growing animals for lean tissue growth and an attempt has been made to present the most current information and to highlight those areas where this information is either lacking or may be misleading.

\section{RELATION BETWEEN PROTEIN AND ENERGY INTAKE}

It is well established that protein deposition can be constrained by an inadequate intake of either protein or energy or both (Black \& Griffiths,1975). However, it is less-well understood that these two inputs exert their effects on protein deposition through separate and independent mechanisms, giving rise to the concept of protein- and energy-dependent phases of lean tissue growth (Campbell et al. 1984). Independent effects of protein and energy intake on protein deposition were first reported in the 1950 s by Blaxter \& Wood (1952) for milk-fed calves. However, the concept is best illustrated by the results of Black \& Griffiths (1975, Fig. 1). In a series of nitrogen-balance studies with lambs of different live weight given diets of various protein content at levels of intake from below maintenance to ad lib., these authors demonstrated that when $\mathrm{N}$ intake was below requirement $\mathrm{N}$ retention was linearly related to $\mathrm{N}$ intake and unaffected by energy intake (proteindependent phase). When $\mathbf{N}$ intake was in excess of requirement $\mathrm{N}$ retention was shown to be related to energy intake and unaffected by $\mathrm{N}$ intake (energy-dependent phase).

Separate protein- and energy-dependent phases of protein accretion have also been demonstrated for pigs (Campbell et al. 1984, 1985a). Although similar information has not been published for commercial avian species it is evident from growth performance and carcass composition findings from broiler chickens given diets of various protein and energy concentration that the same concepts apply (Farrell et al. 1976, 1977; Leclercq, 1983; Pesti \& Smith, 1984; Gous \& Morris, 1985). This has also been confirmed by the results of recently-completed studies at the author's laboratory in which protein accretion was measured by comparative slaughter in male and female broiler chickens given diets ranging in lysine content from 4.6 to $18.4 \mathrm{~g} / \mathrm{kg}$ either at ad lib. or at 0.6 of $\mathrm{ad} \mathrm{lib}$. levels of feeding (R. G. Campbell and R. J. Johnson, unpublished results).

Knowledge of the separate effects of protein and energy intake on protein accretion is crucial for distinguishing between nutritional situations in which lean tissue growth might 


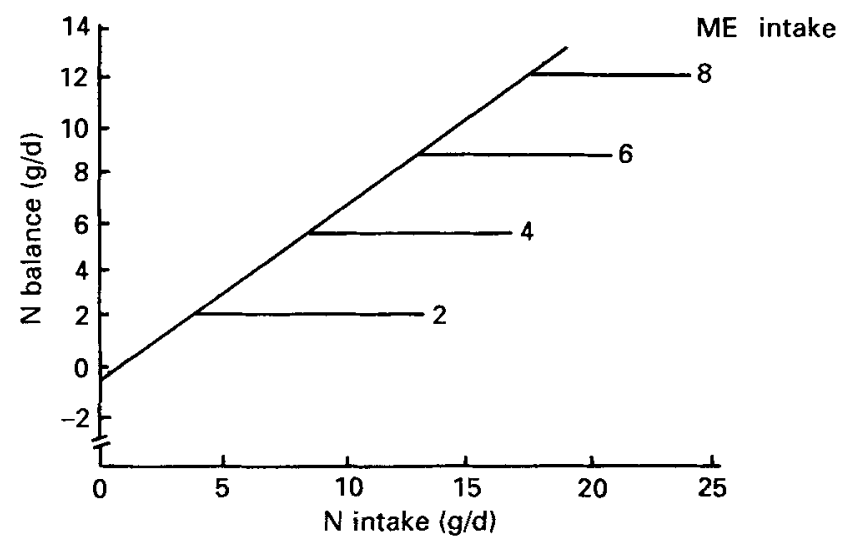

Fig. 1. Relationship between nitrogen balance and $\mathrm{N}$ intake at different metabolizable energy (ME) intakes $(\mathrm{MJ} / \mathrm{d})$ in liquid-fed lambs of $5 \mathrm{~kg}$ (from Black \&Griffiths, 1975).

be constrained by energy or protein intake. Under conditions of dietary protein deficiency lean tissue growth can be increased by raising the protein concentration of the diet or by increasing feed intake. However, in both cases the response is related to the associated increase in protein intake; the rate of improvement in protein accretion per unit increase in protein intake is directly related to the digestibility and biological value (BV) of the dietary protein (Black \& Griffiths, 1975; Campbell \& Dunkin, $1983 a, b$ ), but independent of the inherent potential of the animal for protein growth.

The effect of increasing the intake of protein-deficient and protein-adequate diets on $\mathrm{N}$ retention is illustrated for baby pigs in Fig. 2. In both cases the only source of dietary protein was ultra-filtered skim-milk powder, and the apparent relationships between $\mathrm{N}$ intake and $\mathrm{N}$ retention were both linear. However, the slope of the relationship for pigs given the protein-deficient diet (0-88) was similar to the BV of milk protein (Hodge, 1974; Williams, 1976), while that for pigs given the protein-adequate diet $(0.46)$ bore no relationship to the $\mathrm{BV}$ of milk protein, since the response was to increasing energy intake and a reflection of the inherent potential of the animal for protein growth.

The effects of raising dietary protein content from an initially-deficient level on protein deposition, feed:gain and body fat content of young pigs offered food ad lib. are shown in Fig. 3. These responses are qualitatively the same for all commercial animal and avian species. When protein synthesis is constrained by protein intake extra energy is available for lipogenesis resulting in high body-fat content and slow and inefficient growth. At a given level of energy intake protein deposition again improves linearly with increasing protein intake until a maximal value determined by level of energy intake and various animal factors, which are discussed in detail later (p. 237), is achieved.

There is evidence from rats, lambs and pigs that, when protein is supplied in excess of the amount needed for maximal protein accretion, heat production is increased and the efficiency of energy utilization is reduced (Hartsook \& Hershberger, 1971; Walker \& Norton, 1971; Holmes et al. 1980; Campbell et al. 1985 b). Under these circumstances lipogenesis is reduced and initially the fat:protein ratio in the gain falls below that of animals given a better-balanced diet. However, because protein deposition under conditions of protein adequacy is a function of energy intake, protein accretion also begins to decline as protein intake exceeds the animal's requirement at the tissue level. Evidence from this laboratory suggests that the decline in protein deposition is more rapid than the associated decline in lipogenesis, particularly in castrated males, females and genetically-inferior 


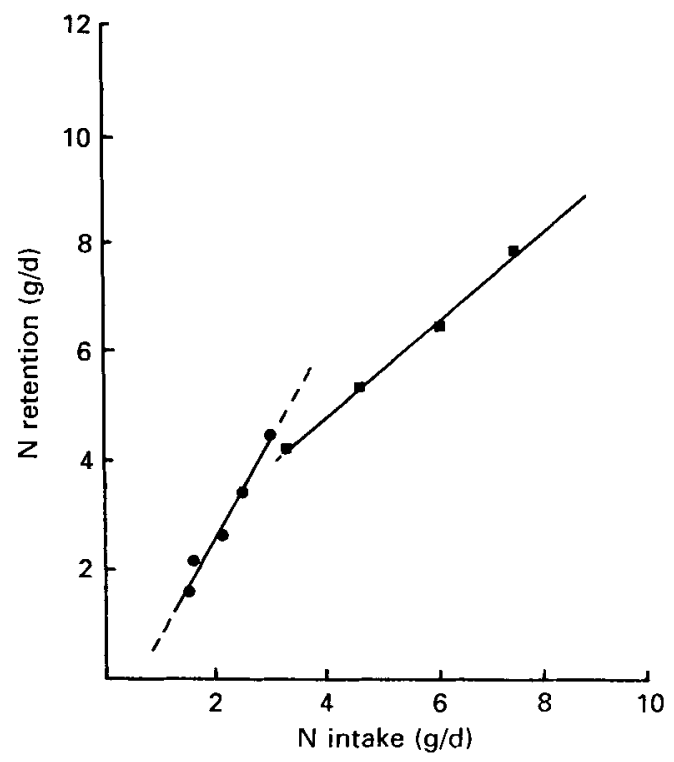

Fig. 2. Apparent relationship between nitrogen retention and $\mathrm{N}$ intake in pigs given a protein-deficient (O) or protein-adequate ( $\square$ ) diet at different levels of intake between 1.8 and $6.5 \mathrm{~kg}$ live weight (Campbell \& Dunkin, 1983a).
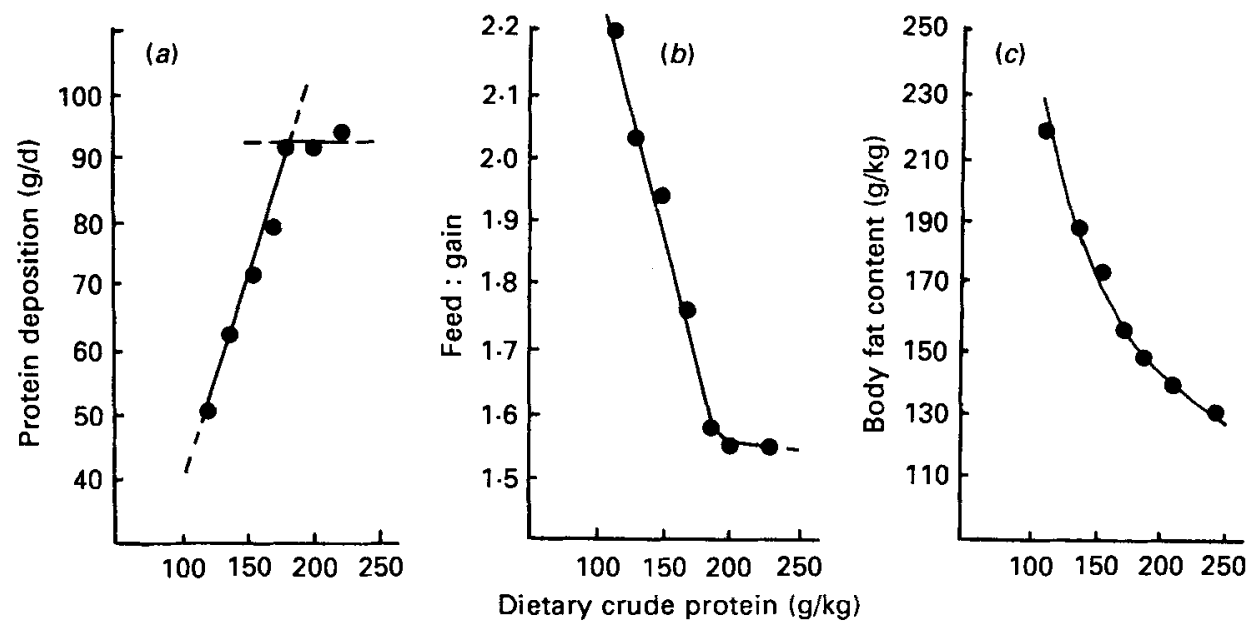

Fig. 3. Effects of dietary protein content on $(a)$ protein deposition $(\mathrm{g} / \mathrm{d}),(b)$ feed:gain $(\mathrm{kg} / \mathrm{kg})$ and $(c)$ body fat content $(\mathrm{g} / \mathrm{kg})$ of pigs offered food ad lib. between 8 and $20 \mathrm{~kg}$ live weight (R. G. Campbell \& M. R. Taverner, unpublished results).

animals, resulting in the fat:protein ratio of gain, and thus body fat content, rising to considerably-higher levels than those of animals given better-balanced diets, and even to the levels exhibited by animals given diets severely deficient in protein (R. G. Campbell \& M. R. Taverner, unpublished results).

Although much of the information given in Figs. 1-3 is not necessarily new, it serves to illustrate current concepts concerning the effects of protein and energy intake on lean tissue 
growth. The findings also demonstrate the extent to which lean tissue growth can be constrained by dietary protein deficiency and that this constraint cannot be removed by simply increasing the intake of a protein-deficient diet.

In practice dietary protein deficiency is unlikely to be a major factor constraining lean tissue growth in commercial simple-stomach animals. Nevertheless, the estimates of dietary protein and amino acid requirements for both pigs and poultry (Agricultural Research Council (ARC), 1975, 1981; National Research Council, 1979, 1984), even for animals or birds of the same age or live weight, vary widely. Much of this variation results from the failure to differentiate between the animal's tissue requirements for protein (amino acids) and the capacity of different diets to satisfy these. Our reluctance in the past to make this distinction means that most estimates of requirement, which are based on the results of experiments in which growth performance was assessed against a range of dietary protein (amino acid) levels, are only applicable to the limited conditions under which they were established.

For pigs the ARC (1981) attempted to resolve this problem by expressing the animal's requirement in terms of a reference or 'ideal' protein based on the amino acid composition of pig tissue. Nevertheless, the usefulness of this approach is presently limited by the lack of appropriate information on the digestibility and availability of amino acids in feed ingredients and by the scarcity of information on the growing pig's tissue requirements for protein and amino acids. The same limitations apply for poultry and these dual problems need to be resolved if diet formulation is to become more accurate than is presently the case.

For ruminants the situation is more complex, since the amount and quality of protein absorbed often bears little relationship to that consumed because of the role of the rumen microbes in influencing $\mathrm{N}$ metabolism. A clearer understanding of the absorption of protein and energy is required to predict more accurately the effects of protein and energy intake on the growth and body composition of ruminants, and to differentiate situations in which lean tissue growth is constrained by energy intake from those in which it might be limited by inadequate protein absorption. The latter is further complicated in ruminants, since low levels of protein absorption are difficult to obtain because of the synthesis of microbial protein from urea recycled to the rumen and the subsequent digestion and absorption of the microbial protein. Alternatively, high levels of protein absorption only occur when dietary proteins are protected from microbial attack in the rumen (Black, 1983). Thus the range of protein absorption in ruminants is generally much less than in simple-stomach animals.

Nevertheless, providing that the dietary protein (amino acids):energy ratio is in excess of requirement the tissue requirements of any animal species can be determined from the relationship between energy intake and protein deposition. Information of this type also enables intrinsic limits to lean tissue growth to be identified and for diets and feeding strategies to be appropriately adjusted.

\section{CONSTRAINTS TO LEAN TISSUE GROWTH UNDER CONDITIONS OF PROTEIN ADEQUACY}

Under these circumstances the partition of energy between protein and fat is determined by the relationship between energy intake and protein deposition (Black \& Griffiths, 1975; Whittemore \& Fawcett, 1976). Knowledge of this relationship is crucial for determining the consequences of change in energy intake on growth performance and body composition, and the design of biologically- and economically-efficient diets and feeding strategies for animals growing over specified live-weight stages. 


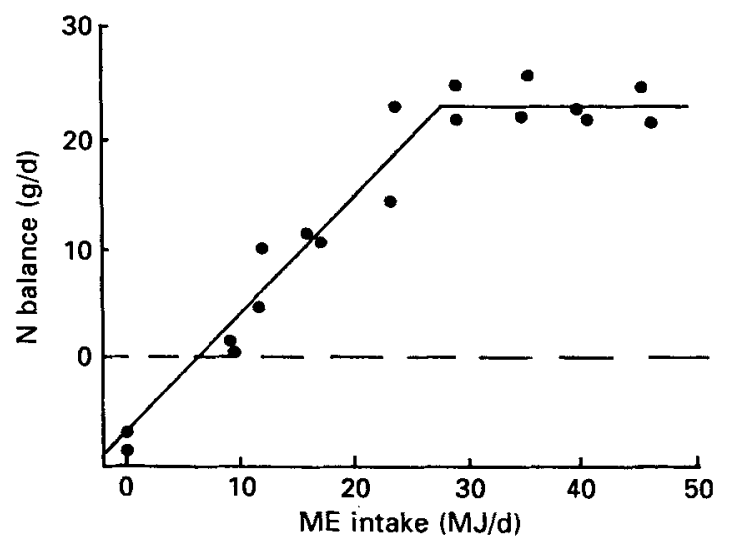

Fig. 4. Relationship between metabolizable energy (ME) intake (MJ/d) and nitrogen balance in entire male pigs weighing $75 \mathrm{~kg}$ (Dunkin et al. 1986).

In order to determine the requirements of growing animals for dietary protein, their growth capacities and their body compositions at any stage of development, quantitative information is required on the relationships between live weight and potential protein and energy accretion rates.

\section{RELATION BETWEEN ENERGY INTAKE AND PROTEIN DEPOSITION}

There is limited support in the literature for each of three alternative response relationships between energy intake and protein deposition, namely linear, curvilinear and linear-plateau. The linear model which proposes that lean tissue growth is constrained primarily by energy intake is supported by the results of experiments with lambs (Black \& Griffiths, 1975) and broiler chickens (Leclercq \& Saadoun, 1982). The ARC (1981) also adopted the linear model to describe the relationship between energy intake and protein deposition for growing pigs. They pointed out, however, that most of the findings reviewed related to young pigs and that the relationship might be modified by factors such as live weight, sex and breed or genotype.

In contrast, Whittemore \& Fawcett (1976) proposed that protein deposition in growing pigs responded linearly to increasing energy intake until a maximum was attained at which the response plateaued. This linear-plateau relationship (Fig. 4), which assumes that maximal lean tissue growth is determined by intrinsic factors, has since been demonstrated experimentally for pigs above $50 \mathrm{~kg}$ live weight (Tullis, 1982; Campbell et al. 1985b; Dunkin et al. 1986) and it is probable that maximal protein deposition is determined by intrinsic factors in all domestic animal species. However, because of their inherently-low appetite, ruminant species, and particularly sheep, probably never consume enough energy to reach maximal protein growth (plateau value). Because of their limited ingestive capacity pigs up to $50 \mathrm{~kg}$ are similarly unable to consume sufficient energy, even when offered diets of high-energy concentration, to reach their ceiling for muscle growth (Campbell et al. 1975; Savidge et al. 1984; Campbell et al. 1986). Consequently for both ruminant species and young pigs the relationship between energy intake and lean tissue growth is essentially linear.

Under these circumstances raising energy intake results in associated linear increases in the rates of deposition of fat, water and ash and thus in growth rate. In contrast the 

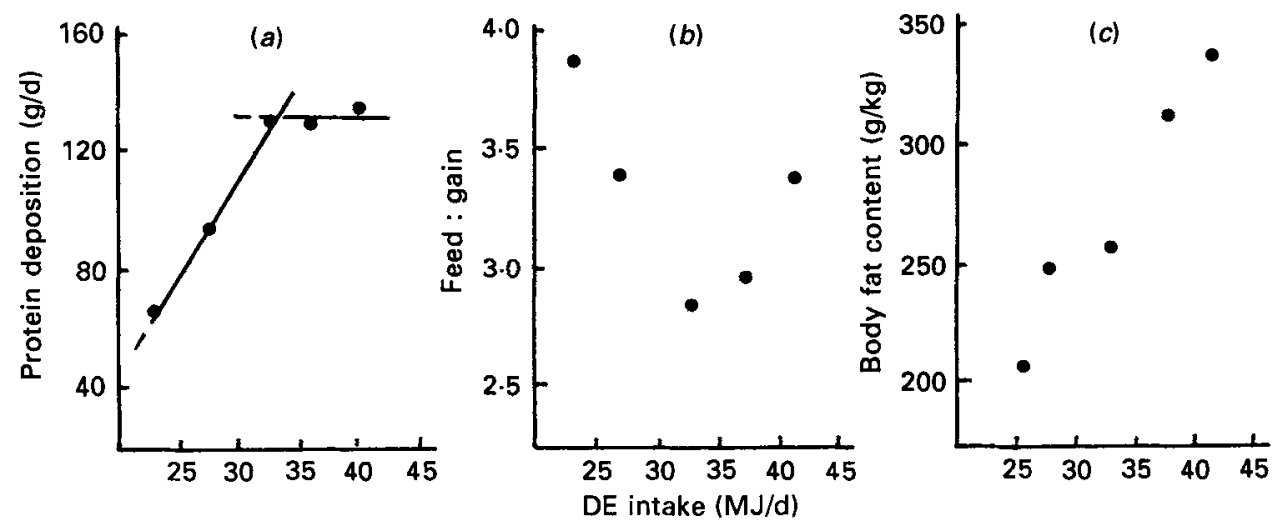

Fig. 5. Effect of digestible energy (DE) intake $(\mathrm{MJ} / \mathrm{d})$ on $(a)$ the rate of protein deposition $(\mathrm{g} / \mathrm{d}),(b)$ feed:gain and $(c)$ body fat content $(\mathrm{g} / \mathrm{kg})$ of entire male pigs growing from 45 to $90 \mathrm{~kg}$ live weight (Campbell et al. 1985b).

feed:gain ratio decreases as energy intake is raised from an initially-low level and approaches a minimal value determined by environmental temperature and dietary energy concentration. Body fat content increases in a curvilinear manner and approaches a maximal value determined by environmental temperature, initial body fat content and in lambs by sex and genotype. These responses have been predicted for lambs (Black \& Griffiths, 1975) and demonstrated for young pigs (Burlacu et al. 1973; Close et al. 1979; Campbell \& Dunkin, 1983a; Campbell et al. 1983). Clearly for animals in which the relationship between energy intake and protein deposition is linear any factor which reduces feed intake or the utilizability of dietary energy will constrain lean tissue growth.

Where the energy intake of an animal is sufficient to maximize protein accretion (reach the plateau) any extra energy supplied is deposited as fat, resulting in an overall decline in the rate and efficiency of growth and marked increase in body fat content. These responses, which are commonly observed in pigs above $50 \mathrm{~kg}$, are illustrated in Fig. 5 .

It was mentioned previously that the limited information available for broiler chickens suggests that the relationship between energy intake and protein deposition is linear (Leclercq \& Saadoun, 1982). However, these results relate to birds with an average live weight of only $1000 \mathrm{~g}$ and the results of recent investigations at the author's laboratory have demonstrated that between 1100 and $2000 \mathrm{~g}$ the relationship between energy intake and protein deposition is in fact of the linear-plateau form in both female and male broiler chickens (R. G. Campbell \& R. J. Johnson, unpublished results). The results also showed that the dietary metabolizable energy (ME) concentration at which protein accretion plateaued $(12.3 \mathrm{MJ} / \mathrm{kg})$ was considerably below that which maximized energy intake and growth rate $(14.3 \mathrm{MJ} / \mathrm{kg})$. These findings suggest that the use of diets formulated to promote maximum growth during the later stages of growth and development may be a major cause of excessive fat development which characterizes many modern-day broiler strains.

Although further information is required, it appears that the general linear-plateau response relationship between energy intake and protein deposition applies for most farm animals. Inherent differences in energy demand between species and in ingestive capacity within a species mean that some animals are continually operating over the linear response phase for lean tissue growth (energy limiting). In others, with high appetites relative to 


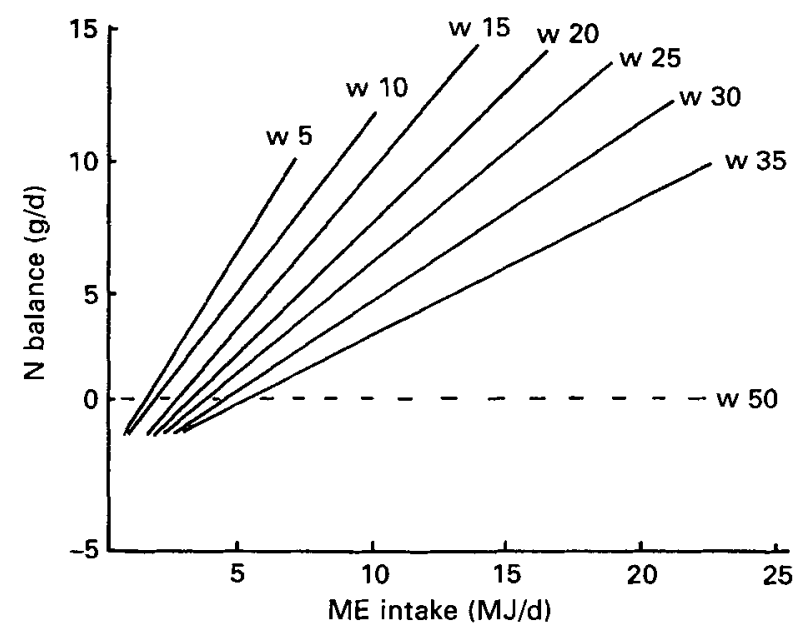

Fig. 6. Relationship between nitrogen balance $(\mathrm{g} / \mathrm{d})$ and metabolizable energy (ME) intake $(\mathrm{MJ} / \mathrm{d})$ of lambs, when $N$ intake was in excess of requirement, at different live weights (w, kg) (Black \& Griffiths, 1975).

maximal protein deposition, potential lean tissue growth may be limited either by energy intake or intrinsic factors. There is evidence, however, that the height and position of the plateau value, and possibly the slope or position of the linear response phase for lean tissue accretion, are influenced by factors such as live weight, sex and genotype.

\section{EFFECTS OF LIVE WEIGHT}

It has been suggested by Whittemore (1986) that for animals of the same species, sex and genotype the slope of the linear component of the relationship between energy intake and protein deposition is largely unaffected by live weight. This proposition, however, is inconsistent with the decline in the rate and efficiency of growth and increase in body fat content which have been demonstrated to accompany increase in live weight in virtuallyall farm animals (Carr et al. 1977; Schneider et al. 1982; Black, 1983; Yen et al. 1986).

The results of Black \& Griffiths (1975) for milk-fed lambs (Fig. 6) indicate that the slope of the linear relationship between energy intake and protein deposition falls with increasing live weight. The results of Dunkin et al. (1984) and Dunkin \& Black (1985) suggest that the slope of the linear component of the relationship is similarly affected by live weight in pigs. These latter authors also suggested that the potential rate of protein accretion (plateau value) increases with live weight up to 70 to $80 \mathrm{~kg}$, after which it begins to fall. There is, however, no other published evidence to support this contention and the true biological response probably lies somewhere between the models proposed by Black \& Griffiths (1975) and Whittemore (1986).

Nevertheless, the results depicted in Fig. 6 and reported by Dunkin \& Black (1985), Schneider et al. (1982) and others clearly demonstrate that as the animal progresses towards maturity, its capacity for protein deposition, even at levels of energy intake below which maximal protein deposition occurs, becomes increasingly constrained by intrinsic rather than nutritional factors. Future improvement in the efficiency of meat production and in carcass leanness will be very-much dependent on the development of techniques to identify and remove these constraints to lean tissue growth. 


\section{EFFECTS OF SEX}

There is ample evidence of differences in growth performance and body composition between entire male and female animals and between these two sexes and castrated males of the same breed and genotype (Searle \& Griffiths, 1976; Webster et al. 1977; Thompson et al. 1979; Williams et al. 1984; Campbell et al. 1985b).

For pigs (Campbell \& Taverner, 1985; Campbell et al. 1985b) and poultry (R. J. Johnson $\&$ R. G. Campbell, unpublished results) there is evidence that sex affects both the linear and horizontal components of the relationship between energy intake and protein deposition. For instance, in a study involving entire male and female pigs Campbell et al. (1985b) reported that protein deposition increased linearly in the two sexes with increase in energy intake up to $33 \mathrm{MJ}$ digestible energy (DE)/d (0.82 ad lib. energy intake) and remained constant thereafter. The results showed, however, that the slopes of both the linear-response phase of protein accretion and the maximal protein accretion were lower for females than for males.

Similar but more dramatic differences in the two components of the linear-plateau relationship between energy intake and protein deposition have been reported between entire and castrated male pigs of the same genotype (Campbell \& Taverner, 1985). However, again maximal protein growth in the two sexes was found to occur at the same absolute level of energy intake (33 MJ DE/d).

The results of these studies and others demonstrate that lean tissue growth is constrained more by intrinsic factors in females and castrated males than in entire males. They clearly implicate the endocrine system, in particular the male and female sex hormones, in the control of protein synthesis and breakdown. This is further demonstrated by the results of Lobley et al. (1985) who reported that the treatment of steers with a combined implant of trenbolone acetate and oestradiol- $17 \beta$ increased protein deposition by $112 \%$. These authors also showed that this improvement in protein deposition was mediated via a relatively-large reduction in protein degradation rather than any stimulus of protein synthesis. Nevertheless, the difference in growth performance reported between the control and treated steers by Lobley et al. (1985) was still considerably below that reported between steers and bulls by Webster et al. (1977) indicating that the trenbolone acetate-oestradiol$17 \beta$ implant was merely returning lean tissue growth towards the higher potential of bulls rather than raising it beyond that determined by the genetic capacity of the animal.

The more quantitative findings of Campbell \& Taverner (1985) demonstrate that because of their higher capacity for lean tissue growth entire male animals will exhibit faster and leaner growth at all levels of energy intake than females or castrated males, but that the deterioration in growth performance and carcass quality resulting from feed intake having exceeded the maximal rate of lean tissue growth will occur at approximately the same level of energy intake. Because they have a higher tissue requirement for protein and amino acids entire males are also more sensitive to dietary protein deficiency than the other two sexes, such that a dietary protein level which promotes maximal lean tissue growth in females or castrated males may seriously constrain that of entire males (Batterham et al. 1985; Yen et al. 1986).

There is also evidence that because of their greater lean body mass entire males have a higher energy requirement for maintenance than females or castrated males (Webster et al. 1978; Campbell et al. 1985 b). This further reduces the energy available for lipogenesis in entire males and enhances between-sex differences in body composition, particularly at low levels of feeding, but at the same time reduces the magnitude of the differences in growth performance which might otherwise be expected from the differences in lean tissue growth. 


\section{EFFECTS OF GENOTYPE}

Numerous experiments have been conducted to compare the growth performance and body composition of different breeds and strains of farm animals (Wood et al. 1975; Gregory et al. 1977; Moody et al. 1978; Theriez et al. 1981; Leclercq \& Saadoun, 1982; Ellis et al. 1983). The consistent finding from most of these experiments has been that at the same weight, genotypes which are heavier at maturity generally grow faster and contain less fat in their empty bodies and carcasses than do animals of smaller mature size. However, because most of these studies involved only a single level of feeding they provide little information on the extent that genotype might modify the relationship between energy intake and protein deposition.

Siebritts \& Kemm (1982) reported differences in maximal lean tissue growth between 'genetically'-lean and -obese strains of gilts offered feed ad lib. from 20 to $110 \mathrm{~kg}$, indicating that the plateau value may be affected by genotype. In a series of studies involving control and selected lines of Large White pigs, Ellis et al. (1983) and Henderson et al. (1983) reported that selected pigs exhibited more rapid and leaner growth under both ad lib. and restricted feeding than their unselected counterparts. The results of these studies suggest that selection under $a d$ lib. feeding may also raise the slope or position of the linearresponse phase of protein accretion. In a more-complete study with 'genetically'-lean and -obese strains of broiler chickens selected under ad lib. feeding conditions, Leclercq \& Saadoun (1982) found that birds of the leaner strain exhibited more-rapid protein accretion at levels of energy intake from 0.5 ad lib. to ad lib.

The extent to which genotype or selection for growth performance can alter an animal's capacity for lean tissue growth is also illustrated by the results of Campbell \& Taverner (1985). In the latter experiment protein deposition was measured by comparative slaughter in two strains of entire male pigs given a diet previously determined to be protein-adequate, at levels of intake ranging from $22 \mathrm{MJ} \mathrm{DE} / \mathrm{d}$ to ad lib., between 45 and $90 \mathrm{~kg}$ live weight. One of the strains (strain A) was from a seventy sow herd and the pigs were representative of animals selected for high growth rate up to 10-12 weeks of age. The second strain (strain B) was from a 6000 sow commercial unit where all pigs have been selected on the basis of growth rate, feed:gain and carcass fat thickness under ad lib. feeding between 50 and $100 \mathrm{~kg}$.

The results, which are summarized in Fig. 7, showed that protein deposition in strain A pigs increased linearly with increase in energy intake up to $32.5 \mathrm{MJ} \mathrm{DE} / \mathrm{d}$ and remained relatively constant at $132 \mathrm{~g} / \mathrm{d}$ thereafter. For strain B pigs, however, there was no evidence of an intrinsic limit to protein accretion which increased linearly with energy intake to $186 \mathrm{~g} / \mathrm{d}$ on the ad lib. feeding treatment (approximately $39 \mathrm{MJ} \mathrm{DE} / \mathrm{d}$ ). These results suggest that the intense selection of these animals (strain B) had raised their genetic ceiling for lean tissue growth beyond the upper limit of appetite. The advantages, in terms of growth performance and body composition, particularly at higher levels of feeding, associated with raising an animal's intrinsic capacity for lean tissue growth are evident from Fig. 7.

Animals of higher genetic potential for lean tissue growth are, however, more sensitive to nutritional stress than those of lower lean tissue growth potential. Empirical studies involving the two strains depicted in Fig. 7 have shown that the level of dietary lysine required to support maximal protein growth in strain B animals is between 18 and $21 \%$ higher than that required for strain A (R. G. Campbell \& M. R. Taverner, unpublished results). Similar differences in the response of 'genetically'-lean and -obese broiler chickens to dietary protein concentration have been reported by Leclercq (1983).

The results of Campbell \& Taverner (1985) also indicate a degree of interdependence 


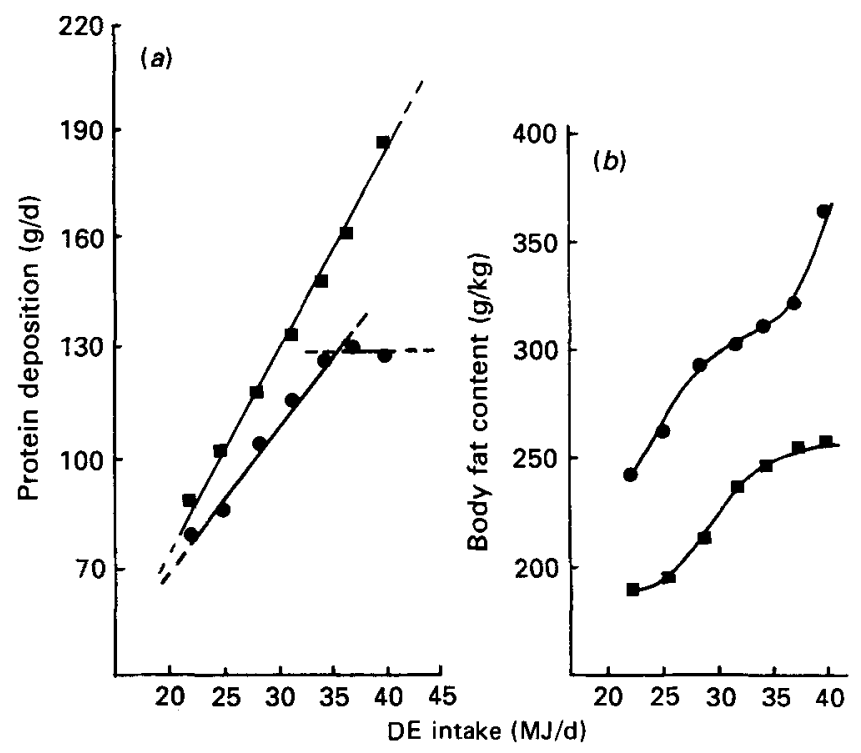

Fig. 7. Effect of digestible energy (DE) intake (MJ/d) between 45 and $90 \mathrm{~kg}$ on (a) protein deposition $(\mathrm{g} / \mathrm{d})$ and $(b)$ body fat content $(\mathrm{g} / \mathrm{kg})$ of two strains of pigs $(\mathrm{O}$, strain $\mathrm{A} ; \square$, strain B) (Campbell \& Taverner, 1985).

between the two components of the linear-plateau relationship between energy intake and protein deposition, since the slope of the relationship for the faster-growing pigs (strain B) was $20 \%$ higher than the linear response phase for the slower-growing animals (strain A). This finding is consistent with the results of Henderson et al. (1983) and Leclercq \& Saadoun (1982), and has been confirmed by recent experiments involving the two pig strains depicted in Fig. 7. The results of these studies showed that up to $50 \mathrm{~kg}$ the relationship between energy intake and protein deposition was linear for both strains. However, at any given level of feeding, protein deposition was $18-22 \%$ higher for the faster-growing strain (strain B) compared to their slower-growing counterparts (strain A). These results show that the selection of animals under ad lib. feeding will increase both maximal protein deposition (plateau value) and, albeit to a smaller extent, the slope and possibly the position of the linear-response phase of protein growth.

Nevertheless, the relative improvement in the two components of the linear-plateau relationship between energy intake and protein deposition is likely to be affected by the nutritional environment during selection. For instance, selection under conditions of restricted energy intake theoretically should result in greater improvement in the slope of the linear-response phase of lean tissue growth than in the plateau value. Such an approach would result in the selection of animals with high growth capacity even at low levels of energy intake, which would be a major advantage under practical situations where the ad lib. energy intake of most commercial animal species is considerably lower than that achieved under more 'ideal' experimental situations. This theory, which is currently being tested with pigs at a large commercial unit in Australia, may also enable improvements in growth performance and carcass quality to be achieved without the same increase in mature body-weight which inevitably accompanies improvements in growth performance using more traditional selection and breed-substitution techniques (Whittemore, 1986).

It is evident from the information discussed in this section that knowledge of the 
relationship between energy intake and protein deposition (Fig. 4) is fundamental to animal-production strategies. Animals with higher lean tissue growth capacities require more dietary protein (amino acids) and at the same level of energy intake will exhibit more rapid and leaner growth than those of lower lean tissue growth potential. Animals with higher lean tissue growth potential can also be given higher levels of energy intake without exhibiting the same deterioration in growth performance and increased carcass fatness as those of lower lean tissue growth potential.

Unfortunately, with the possible exception of pigs there is little quantitative information on the relationship between energy intake and protein deposition. If our understanding of the interrelationships between the various animal factors and nutrition on growth and body composition is to be increased this situation will have to be addressed.

\section{RELATION BETWEEN LIVE WEIGHT AND POTENTIAL PROTEIN DEPOSITION}

Knowledge of the basic relationships between live weight and maximal protein and energy accretion rates is basic to understanding how the nutrient requirements of an animal change as it grows, and for predicting its body composition and growth capabilities at any stage of development between birth and maturity.

Evidence from sheep (Black, 1983; Butterfield et al. 1983) and pigs (Carr et al. 1977; Black et al. 1986) indicates that the relationship between live weight and protein deposition is quadratic in nature, with maximal protein growth occurring at $40-50 \%$ of mature bodyweight and then gradually falling back to zero at maturity. However, because lean tissue growth in young animals is commonly limited by energy intake it is possible that under truly unlimited nutritional circumstances maximal protein deposition could be achieved early in life and remain constant over a wide live-weight range before falling to zero at maturity (Whittemore, 1986).

Clearly it is important to establish which of these two relationships is correct. For pigs, and to a lesser extent sheep, there is probably adequate information in the literature to describe accurately the ascending response phase of protein accretion (Hodge 1974; Siebritts \& Kemm 1982; Campbell et al. 1985 b; Siebritts et al. 1986). On the other hand, the two critical values needed to describe the descending response phase are mature body size and composition. Because of the long-term nature of studies required to obtain this information, particularly with the larger animal species, it is perhaps not surprising that this information is extremely limited. The modelling approaches of Whittemore \& Fawcett (1976), Searle \& Griffiths (1976), Black et al. (1986) and others clearly demonstrate the importance of these longer-term studies. The accuracy of these simulation models and our knowledge of growth and development will remain limited until the appropriate information becomes available.

A number of longer-term programmes with both sheep and pigs are either underway or have recently been completed at the author's laboratory and others in Australia. Combined with the results of Tullis (1982), for pigs grown under full feeding from birth to maturity, this information should enable the relationships between live weight and potential protein and energy accretion to be established at least for a limited number of genotypes within each species.

\section{ENHANCEMENT OF LEAN TISSUE GROWTH}

It was mentioned previously that future improvement in the efficiency of the livestock industries will rely on removing the various intrinsic constraints on protein deposition and raising lean tissue growth beyond what are presently considered 'normally'-high levels 


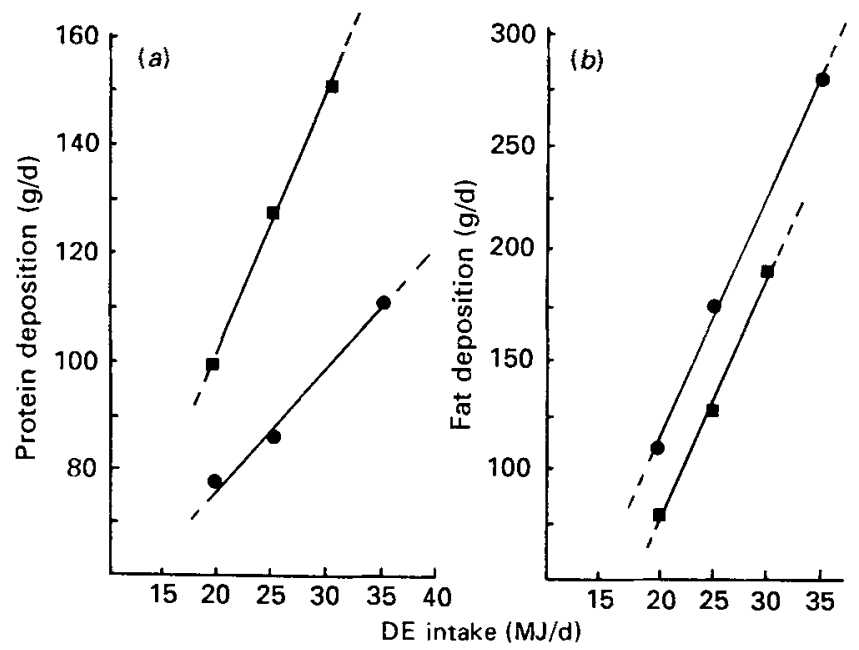

Fig. 8. Relationship between digestible energy (DE) intake (MJ/d) and (a) protein deposition (g/d) and (b) fat deposition $(\mathrm{g} / \mathrm{d})$ in control pigs $(O)$ and pigs administered porcine growth hormone $(\square)$ between 25 and $55 \mathrm{~kg}$ live weight (Campbell et al. 1987).

under optimal nutritional conditions. The findings presented in Fig. 7 demonstrate the extent to which this is achievable by intense selection on the basis of growth performance. However, recent advances in biotechnology, in particular recombinant DNA and peptide technology, has provided scientists with a range of materials and techniques for altering energy and protein metabolism, and an unparalleled opportunity to probe the mechanisms controlling growth and development.

Except for a brief final section on foreign gene transfer discussion of these techniques has been limited to exogenous $\mathrm{GH}$ administration largely because considerable new information has recently become available, and it appears that this technology has a more direct, and certainly a more pronounced, effect on lean tissue growth than most of the others currently available.

\section{EXOGENOUS GROWTH HORMONE ADMINISTRATION}

The results of experiments using exogenous $\mathrm{GH}$ administration in sheep, cattle and pigs indicate that the endocrine system, and endogenous GH secretion in particular, is a major factor constraining lean tissue growth in these species. However, while the changes in growth performance and body composition elicited by exogenous GH therapy in these species have been dramatic (Machlin, 1972; Chung et al. 1985; Johnsson et al. 1985; Boyd et al. 1986; Etherton et al. 1986, 1987; Butler-Hogg \& Johnsson 1987) there is little information on the underlying changes in protein and energy metabolism. There is also little information on how the animal's responsiveness to GH administration might be modified by nutrient intake or its inherent capacity for protein growth. Answers to some of these questions are provided in Fig. 8 and in Tables $1-4$ which summarize the results of a series of recently-completed experiments conducted with growing pigs in Australia and the USA.

The effects of exogenous porcine $\mathrm{GH}(\mathrm{pGH})$ administration $(0 \cdot 1 \mathrm{mg} / \mathrm{kg}$ per d) on the rates of protein and of fat deposition in the empty bodies of castrated male pigs given a single diet at three levels of energy intake ranging from $20 \cdot 1 \mathrm{MJ} \mathrm{DE} / \mathrm{d}$ to ad lib. between 25 and $55 \mathrm{~kg}$ live weight are shown in Fig. 8. GH administration reduced ad lib. energy 
Table 1. Effects of digestible energy (DE) intake and exogenous porcine pituitary growth hormone ( $p G H)$ administration on the performance and body composition of castrated male pigs growing from 25 to $55 \mathrm{~kg}$ (Campbell et al. 1987)

\begin{tabular}{|c|c|c|c|c|c|c|c|}
\hline \multirow{2}{*}{$\begin{array}{c}\text { Energy intake }(\mathrm{MJ} \mathrm{DE} / \mathrm{d}) \ldots \\
\text { pGH }(\mathrm{mg} / \mathrm{kg} \text { per d)... }\end{array}$} & \multicolumn{2}{|c|}{$20 \cdot 1$} & \multicolumn{2}{|c|}{$24 \cdot 3$} & \multicolumn{2}{|c|}{ Ad lib. } & \multirow[b]{2}{*}{ SEM } \\
\hline & 0.0 & $0 \cdot 1$ & 0.0 & $0 \cdot 1$ & 0.0 & 0.1 & \\
\hline \multicolumn{8}{|l|}{ Performance: } \\
\hline Feed intake $(\mathrm{kg} / \mathrm{d})$ & $1 \cdot 30$ & 1.31 & 1.61 & 1.61 & $2 \cdot 32$ & $2 \cdot 05$ & 0.02 \\
\hline Daily gain (g) & 543 & 681 & 670 & 842 & 905 & 1051 & $20 \cdot 0$ \\
\hline Feed : gain $(\mathrm{kg} / \mathrm{kg})$ & $2 \cdot 54$ & 1.92 & 2.45 & 1.92 & 2.57 & 1.96 & 0.03 \\
\hline \multicolumn{8}{|l|}{ Body composition $(\mathrm{g} / \mathrm{kg})$ : } \\
\hline Water & 602 & 656 & 575 & 642 & 566 & 617 & $6 \cdot 0$ \\
\hline Protein & 163 & 173 & 154 & 169 & 146 & 162 & $2 \cdot 0$ \\
\hline Fat & 196 & 141 & 231 & 153 & 258 & 188 & $7 \cdot 0$ \\
\hline Ash & $25 \cdot 1$ & $27 \cdot 2$ & $25 \cdot 0$ & $25 \cdot 6$ & $26 \cdot 2$ & $31 \cdot 4$ & $1 \cdot 1$ \\
\hline
\end{tabular}

intake by $14 \%$, but increased protein deposition at equivalent levels of energy intake by up to $51 \%$ and reduced fat deposition by $31 \%$, resulting in a marked reduction in the fat: protein ratio of energy gain and in body fat content at $55 \mathrm{~kg}$ live weight (Table 1). The results demonstrate that even during the relatively-early period of development investigated in this experiment endogenous $\mathrm{GH}$ secretion is a major factor limiting protein growth in the pig. The linear relationships found between energy intake and protein deposition also illustrate that in younger animals maximal protein deposition remains a function of energy intake, and that exogenous GH administration cannot raise lean tissue growth beyond the upper limit set by nutrient intake.

The linear and almost threefold increase in the rate of fat deposition with increasing energy intake (Fig. 8) found for pGH-treated pigs also indicates that the direct inhibition of lipogenesis in adipose tissue by GH (Walton \& Etherton 1986; Walton et al. 1986, 1987) is only partial and not the only reason for the associated decline in body fat content observed in GH-treated animals.

The role of $\mathrm{GH}$ in the regulation of protein metabolism is further illustrated in Table 2, which summarizes the results of an experiment involving boars, gilts and castrated male pigs administered pGH for $31 \mathrm{~d}$ commencing at $60 \mathrm{~kg}$ live weight. Control boars exhibited faster protein deposition and more rapid and leaner growth than castrated males, with gilts being intermediate. However, pGH administration raised protein deposition to the same absolute level in the three sexes and effectively eliminated the well-established differences in feed:gain and body composition between the sexes. The average protein deposition rate exhibited by the pGH-treated animals $(235 \mathrm{~g} / \mathrm{d})$ is also almost $25 \%$ above the highest level previously reported for pigs of any sex.

These results indicate the existence of an upper limit or true genetic ceiling for lean tissue growth and show that because of differences in endocrine status entire males are operating closer to this ceiling and, as such, are less responsive to exogenous pGH administration than females or castrated males.

Comprehensive serial-bleeding studies conducted in conjunction with the performance study discussed previously showed that boars and castrated males exhibited a similar level and pattern of endogenous $\mathrm{GH}$ release. The release of $\mathrm{GH}$ from the pituitary in response to a challenge with GH-releasing factor was also found to be identical for boars and castrated males (J.P. McMurtry, unpublished results) demonstrating that the anabolic actions of the male sex hormones are not necessarily mediated through the GH axis. 
Table 2. Effects of exogenous porcine growth hormone ( $p G H)$ administration for $31 d$ on the growth performance, body composition and tissue accretion rates of entire male, female and castrated male pigs with an initial live weight of $60 \mathrm{~kg}$ (R. G. Campbell, N. C. Steele, C. P. Caperna, J. P. McMurtry \& M. C. Solomon, unpublished results)

\begin{tabular}{|c|c|c|c|c|c|c|c|}
\hline \multirow{2}{*}{$\begin{array}{l}\text { Sex... } \\
\text { pGH (mg/kg per d)... }\end{array}$} & \multicolumn{2}{|c|}{ Entire male } & \multicolumn{2}{|c|}{ Female } & \multicolumn{2}{|c|}{ Castrated male } & \multirow[b]{2}{*}{ SEM } \\
\hline & 0.0 & $0 \cdot I$ & $0 \cdot 0$ & 0.1 & $0 \cdot 0$ & $0 \cdot 1$ & \\
\hline \multicolumn{8}{|l|}{ Growth performance } \\
\hline Feed intake* & $3 \cdot 21$ & $2 \cdot 96$ & $3 \cdot 37$ & $2 \cdot 73$ & 3.67 & $2 \cdot 84$ & $0 \cdot 13$ \\
\hline Daily gain & 1185 & 1341 & 1010 & 1237 & 1057 & 1224 & $42 \cdot 0$ \\
\hline Feed : gain & $2 \cdot 72$ & $2 \cdot 21$ & $3 \cdot 34$ & $2 \cdot 21$ & 3.45 & $2 \cdot 32$ & 0.07 \\
\hline \multicolumn{8}{|l|}{ Body composition $(\mathrm{g} / \mathrm{kg})$} \\
\hline Water & 563 & 611 & 524 & 604 & 514 & 589 & $8 \cdot 0$ \\
\hline Protein & 167 & 178 & 158 & 179 & 145 & 173 & $2 \cdot 0$ \\
\hline Fat & 234 & 181 & 290 & 185 & 313 & 210 & $7 \cdot 0$ \\
\hline Ash & 24 & 25 & 23 & 27 & 24 & 24 & $1 \cdot 0$ \\
\hline \multicolumn{8}{|l|}{ Tissue accretion rates $(\mathrm{g} / \mathrm{d})$} \\
\hline Water & 467 & 676 & 342 & 680 & 382 & 616 & $27 \cdot 0$ \\
\hline Protein & 196 & 238 & 148 & 232 & 139 & 234 & $9 \cdot 0$ \\
\hline Fat & 316 & 202 & 410 & 185 & 462 & 222 & $25 \cdot 0$ \\
\hline Ash & 24 & 30 & 24 & 38 & 27 & 29 & 10 \\
\hline Fat:protein ratio & 1.64 & 0.87 & $2 \cdot 82$ & 0.80 & $3-45$ & 0.99 & $0 \cdot 15$ \\
\hline
\end{tabular}

* All pigs offered a single diet ad lib.

Table 3. Effects of exogenous porcine pituitary growth hormone ( $p G H$ ) administration on the performance, and protein and fat accretion rates in the eviscerated carcass of entire male pigs representing fast- (strain $A$ ) and slower-growing (strain B) genotypes offered feed ad lib. from 60 to $90 \mathrm{~kg}$ (R.G. Campbell, M.R. Taverner \& R. J. Johnson, unpublished results)

\begin{tabular}{|c|c|c|c|c|c|c|c|}
\hline \multirow[b]{2}{*}{ Strain } & \multirow[b]{2}{*}{$\begin{array}{c}\text { pGH } \\
(\mathrm{mg} / \mathrm{kg} \text { per } \mathrm{d})\end{array}$} & \multicolumn{3}{|c|}{ Performance } & \multicolumn{3}{|c|}{ Tissue accretion rates } \\
\hline & & $\begin{array}{l}\text { Feed intake } \\
\qquad(\mathrm{kg} / \mathrm{d})\end{array}$ & $\begin{array}{l}\text { Daily gain } \\
\text { (g) }\end{array}$ & $\begin{array}{l}\text { Feed : gain } \\
(\mathrm{g} / \mathrm{g})\end{array}$ & $\begin{array}{l}\text { Protein } \\
(\mathrm{g} / \mathrm{d})\end{array}$ & $\begin{array}{l}\text { Fat } \\
(\mathrm{g} / \mathrm{d})\end{array}$ & $\begin{array}{l}\text { Fat:protein } \\
\text { ratio }\end{array}$ \\
\hline \multirow[t]{2}{*}{ A } & 0 & $3 \cdot 14$ & 1180 & $2 \cdot 70$ & 153 & 275 & 1.80 \\
\hline & 0.1 & 2.76 & 1520 & 1.82 & 251 & 134 & 0.54 \\
\hline \multirow[t]{2}{*}{ B } & 0 & 3.24 & 992 & $3 \cdot 30$ & 110 & 355 & $3 \cdot 22$ \\
\hline & 0.1 & 2.61 & 1290 & 2.03 & 189 & 188 & 0.99 \\
\hline SEM & & 0.13 & $49 \cdot 4$ & 0.09 & 11.0 & $29 \cdot 0$ & 0.04 \\
\hline
\end{tabular}

The results of a recently-completed experiment involving the fast- and slower-growing strains depicted in Fig. 7, and designed to determine if the upper limit to protein deposition is common to all pigs or is a function of genotype are summarized in Table 3 . The results again showed that pGH administration eliminated the differences in feed:gain and carcass composition between boars and gilts within each strain (results not presented). However, the proportional improvement in growth performance and change in body composition elicited by $\mathrm{pGH}$ was independent of strain, indicating that the upper limit or genetic ceiling for lean tissue growth is a function of genotype. This was confirmed by the results for tissue growth which showed that $\mathrm{pGH}$ administration raised protein deposition in the eviscerated carcass of boars of the fast- and slower-growing strains from 153 to $245(60.1 \%)$ and from 110 to $190(71.8 \%) \mathrm{g} / \mathrm{d}$ respectively. 
Table 4. Comparative growth performance of pigs transgenic for bovine growth hormone (TG) and their control litter-mates (C) given feed ad lib. or in restricted amounts between 30 and $60 \mathrm{~kg}$ live weight (R.G. Campbell \& V. G. Pursel, unpublished results)

(Values are means with their standard errors)

\begin{tabular}{|c|c|c|c|c|c|c|c|c|}
\hline \multirow[b]{2}{*}{ Feeding } & \multirow[b]{2}{*}{ Pig type } & \multirow[b]{2}{*}{$n$} & \multicolumn{2}{|c|}{$\begin{array}{l}\text { Feed intake } \\
(\mathrm{kg} / \mathrm{d})\end{array}$} & \multicolumn{2}{|c|}{$\begin{array}{l}\text { Daily gain } \\
\text { (g) }\end{array}$} & \multicolumn{2}{|c|}{ Feed:gain } \\
\hline & & & Mean & $\mathrm{SE}$ & Mean & $\mathbf{S E}$ & Mean & $\mathbf{S E}$ \\
\hline \multirow{2}{*}{ Ad lib. } & $\mathrm{C}$ & 8 & 2.04 & 0.05 & 778 & 42 & $2 \cdot 67$ & 0.05 \\
\hline & TG & 3 & $2 \cdot 11$ & 0.06 & 988 & 38 & $2 \cdot 11$ & 0.06 \\
\hline \multirow{2}{*}{ Restricted } & $\mathrm{C}$ & 8 & 1.86 & 0.05 & 732 & 46 & $2 \cdot 61$ & 0.14 \\
\hline & TG & 5 & 1.87 & 0.08 & 837 & 59 & $2 \cdot 22$ & 0.22 \\
\hline \multicolumn{9}{|l|}{ Statistical significance } \\
\hline Feeding level $(\mathbf{F})$ & & & & ** & & * & & NS \\
\hline Pig type (P) & & & & NS & & *** & & * \\
\hline$F \times P$ & & & & NS & & NS & & NS \\
\hline
\end{tabular}

NS, not significant $(P>0.05)$.

* $P<0.05, * * P<0.01$.

Evidence with rats (Albertsson-Wikland et al. 1979, 1980) and cattle (Eisemann et al. 1986) indicate that the improvement in protein deposition elicited by $\mathrm{GH}$ is associated with stimulation of protein synthesis and possibly inhibition of protein breakdown. It is also probable that both these effects are mediated via the somatomedins (Jacob et al. 1987).

Regardless of the mechanism, it is evident from the results in Tables 2 and 3 that exogenous $\mathrm{GH}$ administration effectively removes the various metabolic and biochemical constrains to lean tissue growth. Nevertheless, the results presented in Table 4 indicate that for slower-growing genotypes the response of lean tissue growth to exogenous GH administration is restrained by other factors. It is possible that one of these factors is the number of primary muscle fibres an animal contains, particularly as this is determined at birth and there is evidence with broiler chickens (Hentges et al. 1983) and young pigs (Campbell \& Dunkin $1983 c$ ) that an animal's capacity for protein synthesis is related to the number of muscle nuceli it contains. At the author's laboratory the effects of exogenous GH administration, sex and genotype on the muscle cell biology of both pigs and chickens are currently being investigated, and an attempt will be made to manipulate the muscle fibre number of pigs in utero using various techniques.

It is also interesting that broiler chickens, unlike pigs, sheep, and cattle are insensitive to exogenous chicken-GH administration during the first $28 \mathrm{~d}$ of life (Leung et al. 1986; Burke et al. 1987). This, however, is not surprising because endogenous GH production in broiler chickens is extremely high during this period of development (Johnson et al. 1985, 1987) and obviously is not a factor constraining lean tissue growth.

The difference in the responsiveness of broiler chickens and mammalian species, particularly pigs, to exogenous $\mathrm{GH}$ administration may be a reflexion of differences in the techniques and intensity of selection employed for the respective species over time. This is further indicated by the results of serial-bleeding studies with the fast- and slower-growing pig strains established at the author's laboratory. These have shown that above $30 \mathrm{~kg} \mathrm{GH}$ secretion is low in both strains, and that the level and pattern of GH release is largely independent of genotype (R. G. Campbell and R. J. Johnson, unpublished results). 


\section{TRANSGENIC ANIMALS}

One of the most exciting developments in our attempts to manipulate animal performance has been the alteration of genetic merit by direct gene transfer. The feasibility of this approach was first demonstrated by the successful incorporation of a number of foreign or transgenes into the mouse genome (for review, see Brinster \& Palmiter, 1986).

Although initial studies aimed at extending this technique to domestic animals proved disappointing (Hammer et al. 1985), more-recent attempts, particularly with pigs, have been somewhat more successful. For instance researchers at the University of Adelaide in Australia have established homozygous breeding lines of pigs harbouring variable copy numbers of the human metallothionein-pGH gene construct. A number of these transgenic animals have exhibited elevated pGH levels and superior growth performance compared to their control litter-mates (Seamark, 1987).

Similarly, scientists at the Beltsville Agricultural Research Center in the USA have produced lines of pigs harbouring various bovine-GH gene constructs. Although there is no direct information on the capacity of such animals for lean tissue growth, the potential of this technique is illustrated in Table 4, which shows the comparative growth performance of eight pigs transgenic for bovine $\mathrm{GH}$ compared with sixteen control animals between 30 and $60 \mathrm{~kg}$ live weight.

The major problem with this technique, at least as it applies to farm animals, is the uncontrolled level of expression of the transgenes (Bolt et al. 1986; Seamark, 1987). Nevertheless, new gene constructs are currently being investigated (Seamark, 1987). If genes for GH, GH-releasing factor or IGF I can be controlled so that they remain latent in breeding stock and their expression is controllable in the germ line, livestock created in this manner could, in the not too distant future, have a significant impact on the efficiency of meat production. As genes from any living species can be transferred in this manner, the potential value of this technology to scientists in improving and investigating animal physiology and production is only limited by our imagination (Wagner, 1985; Brinster \& Palmiter 1986; Seamark, 1987).

\section{CONCLUSIONS}

Nutrient restriction can act as a major constraint to expression of lean tissue growth potential in farm animals. However, the dietary nutrient requirements of growing animals are determined by their capacity for protein growth, which in turn is determined by factors such as live weight, sex and genotype. Furthermore, the growth performance and body composition exhibited under any particular set of circumstances is largely a refiexion of the extent that lean tissue growth is constrained by these various animal factors and by the nutritional and climatic environments.

Recent information indicates that because of constraints imposed on protein metabolism by the endocrine system and by endogenous GH secretion in particular, most farm animals, with the possible exception of broiler chickens, are operating considerably below their true genetic potential for lean tissue growth.

Exogenous GH administration and related technologies (e.g., use of GH-releasing peptides, and gene transfer) have the potential for raising lean tissue accretion, certainly in pigs and possibly in ruminant species, to levels not previously thought biologically possible, and for reducing body and carcass fat content in animals of high mature body-weight to levels presently only observed during the early stages of post-natal growth and development.

These new technologies, however, will not negate the basic relationships which have been 
established between nutrient intake and protein and energy metabolism. Indeed, if more quantitative information was available on the extent to which these different techniques alter the partition of energy between maintenance and protein and lipid metabolism their effects on growth performance, body composition and dietary nutrient requirements could be predicted. Unfortunately, most of the experiments conducted to date have involved only a single diet, generally offered $a d$ lib., and too often have only provided information on growth performance and carcass characteristics.

Clearly if the potential of these new technologies is to be assessed fully, their effects on protein and energy metabolism need to be investigated over a wide range of dietary situations and in animals with inherently-different capacities for lean tissue growth.

From a scientific aspect, these new technologies have the potential to increase our understanding of metabolic and biochemical mechanisms controlling growth and development, and hopefully will enable us to identify means by which these control systems may be broken down or manipulated to result in further enhancement of lean tissue growth.

\section{REFERENCES}

Agricultural Research Council (1975). The Nutrient Requirements of Farm Livestock No. 1, Poultry, 2 nd ed. London: H.M. Stationery Office.

Agricultural Research Council (1981). The Nutrient Requirements of Pigs. 2nd ed. Slough: Commonwealth Agricultural Bureaux.

Albertsson-Wikland, K., Eden, S. \& Isaksson, O. (1979). In vitro effects of growth hormone on protein synthesis and amino acid transport in the rat diaphragm after acute hypophsectomy. Acta Physiologica Scandanavica 105, 215-222.

Albertsson-Wikland, K., Eden, S. \& Isaksson, O. (1980). Analysis of early responses to growth hormone on amino acid transport and protein synthesis in diaphragms of young rats. Endocrinology 106, 291-298.

Batterham, E. S., Giles, L. R. \& Dettmann, B. E. (1985). Amino acid and energy interactions in growing pigs. 2. Effects of food intake, sex and live weight on responses to lysine concentration in barley based diets. Animal Production 42, 133-144.

Black, J. L. (1983). Growth and development of lambs. In Sheep Production, pp. 21-58 [W. Haresign, editor] London: Butterworths.

Black, J. L., Campbell, R. G., Williams, I. H., James, K. J. \& Davies, G. T. (1986). Simulation of energy and amino acid utilization in the pig. Research and Development in Agriculture $3,121-145$.

Black, J. L. \& Griffiths, D. A. (1975). Effects of live weight and energy intake on nitrogen balance and total N requirements of lambs. British Journal of Nutrition 33, 399-413.

Blaxter, K. L. \& Wood, W. A. (1952). The nutrition of the young Ayrshire calf. Journal of Nutrition 6, 1-11.

Bolt, D. J., Pursel, V. G., Hammer, R. E., Wall, R. J., Palmiter, R. D. \& Brinster, R. L. (1986). Plasma concentrations of human growth hormone and porcine growth hormone in transgenic pigs. Journal of Animal Science 63, suppl. 1, p. 220 Abstr.

Boyd, D. R., Bauman, D. E., Beerman, D. H., DeNeergard, A. F., Souza, L. \& Butler, W. R. (1986). Titration of the bovine growth hormone dose which maximizes growth performance and lean deposition in swine. Journal of Animal Science 63, Suppl. 1, 218.

Brinster, R. L. \& Palmiter, R. D. (1986). Introduction of genes into the germ lines of animals. Harvey Lectures, 80, $1-38$.

Burke, W. H., Moore, J. A., Ogez, J. \& Builder, S. E. (1987). The properties of recombinant chicken growth hormone and its effects on growth, body composition, feed efficiency and other factors in broiler chickens. Endocrinology 120, 651-658.

Burlacu, G., Baia, G., Ionila, D., Moisa, D., Tascenco, V., Visan, I. \& Stoica, I. (1973). Efficiency of the utilization of the energy of food in piglets, after weaning. Journal of Agricultural Science, Cambridge 81, $295-302$.

Butterfield, R. M., Griffiths, D. A., Thompson, J. M., Zamora, J. \& James, A. M. (1983). Changes in body composition relative to weight and maturity of large and small strains of Australian Merino rams. 1. Muscle, bone and fat. Animal Production 36, 29-38.

Butler-Hogg, B. W. \& Johnsson, I. D. (1987). Bovine growth hormone in lambs: effects on carcass composition and tissue distribution in crossbred females. Animal Production 44, 117-124.

Campbell, R. G., Caperna, T. J., Steele, N. C. \& Mitchell, A. D. (1987). Effects of porcine pituitary growth hormone $(\mathrm{pGH})$ administration and energy intake on growth performance of pigs from $25-55 \mathrm{~kg}$ body weight. Journal of Animal Science 65. Suppl, 1, p. 244 Abstr.

Campbell, R. G. \& Dunkin, A. C. (1983a). The effects of energy intake and dietary protein on nitrogen retention, 
growth performance, body composition and some aspects of energy metabolishm of baby pigs. British Journal of Nutrition 49, 221-230.

Campbell, R. G. \& Dunkin, A. C. (1983b). The influence of dietary protein and energy intake on the performance, body composition and energy utilization of pigs from 7 to $19 \mathrm{~kg}$. Animal Production 36, 185-192.

Campbell, R. G. \& Dunkin, A. C. $(1983 c)$. The influence of protein nutrition in early life on growth and development of the pig. 2. Effects on the cellularity of muscle and subcutaneous adipose tissue. British Journal of Nutrition 50, 619-626.

Campbell, R. G. \& Taverner, M. R. (1985). Effect of strain and sex on protein and energy metabolism in growing pigs. In Energy Metabolism of Farm Animals. European Association of Animal Production Publication no. 32, pp. 78-81 [R. W. Moe, H. F. Tyrell and P. J. Reynolds, editors]. New Jersey: Rowman and Littlefield.

Campbell, R. G., Taverner, M. R. \& Curic, D. M. (1983). The influence of feeding level from 20 to $45 \mathrm{~kg}$ live weight on the performance and body composition of female and entire male pigs. Animal Production 36, 193-199.

Campbell, R. G., Taverner, M. R. \& Curic, D. M. (1984). Effect of feeding level and dietary protein content on the growth, body composition and rate of protein deposition in pigs growing from 45 to $90 \mathrm{~kg}$. Animal Production 38, 233-240.

Campbell, R. G., Taverner, M. R. \& Curic, D. M. $(1985 a)$. The influence of feeding level on the protein requirement of pigs between 20 and $45 \mathrm{~kg}$ live weight. Animal Production 40, 489-496.

Campbell, R. G., Taverner, M. R. \& Curic, D. M. (1985b). Effects of sex and energy intake between 48 and $90 \mathrm{~kg}$ live weight on protein deposition in growing pigs. Animal Production 40, 497-503.

Campbell, R. G., Taverner, M. R. \& Curic, D. M. (1986). The effects of dietary fibre, source of fat and dietary energy concentration on the voluntary food intake and performance of growing pigs. Animal Production 43, $327-334$.

Campbell, R. G., Taverner, M. R. \& Mullaney, P. D. (1975). The effects of dietary concentrations of digestible energy on the performance and carcass characteristics of early-weaned pigs. Animal Production 21, 285-294.

Carr, J. R., Boorman, K. N. \& Cole, D. J. A. (1977). Nitrogen retention in the pig. British Journal of Nutrition 37, $143-155$.

Chung, C. S., Etherton, T. D. \& Wiggins, J. P. (1985). Stimulation of swine growth by porcine growth hormone. Journal of Animal Science 60, 118-130.

Close, W. H., Stainer, M. W. \& Sanz Sampelayo, M. R. (1979). The energy requirements for growth in the earlyweaned pig. Proceedings of the Nutrition Society $38,47 \mathrm{~A}$.

Dunkin, A. C. \& Black, J. L. (1985). The relationships between energy intake and nitrogen balance in the growing pig. In Energy Metabolism of Farm Animals. European Association of Animal Production Publication no. 32, pp. 110-114 [P. W. Moe, H. F. Tyrell and P. J. Reynolds, editors]. New Jersey: Rowman and Littlefield.

Dunkin, A. C., Black, J. L. \& James, K. J. (1984). Relationship between energy intake and nitrogen retention in the finisher pig. Proceedings of the Australian Society of Animal Production 15, 672 Abstr.

Dunkin, A. C., Black, J. L. \& James, K. J. (1986). Nitrogen balance in relation to energy intake in entire male pigs weighing $75 \mathrm{~kg}$. British Journal of Nutrition 55, 201-207.

Eisemann, J. H., Hammond, A. C., Bauman, D. E., Reynolds, P. J., McCutcheon, S. N., Tyrell, H. F. \& Haaland, G. L. (1986). Effect of bovine growth hormone administration on metabolism of growing Hereford heifers: protein and lipid metabolism and plasma concentrations of metabolites and hormones. Journal of Nutrition 116, 2504-2511.

Ellis, M., Smith, W. C., Henderson, R., Whittemore, C. T. \& Laird, R. (1983). Comparative performance and body composition of control and selection line Large White pigs. 2. Feeding to appetite for a fixed time. Animal Production 36, 407-413.

Etherton, T. D., Wiggins, J. P., Chung, C. S., Evock, C. M., Rebhun, J. F. \& Walton, P. E. (1986). Stimulation of pig growth performance by porcine growth hormone and growth hormone releasing factor. Journal of Animal Science 63, 1389-1399.

Etherton, T. D., Wiggins, J. P., Chung, C. S., Evock, C. M., Rebhun, S. F., Walton, P. E. \& Steele, N. C. (1987). Stimulation of pig growth performance by porcine growth hormone: Determination of the dose-response relationship. Journal of Animal Science 64, 433-442.

Farrell, D. J., Hardaker, J. B., Battse, G. E. \& Cumming, R. B. (1977). Effects of variation in dietary energy concentration of starter and finisher diets on broiler production. Australian Journal of Experimental Agriculture and Animal Husbandry 17, 755-760.

Farrell, D. J., Hardaker, J. R., Greig, I. D. \& Cumming, R. B. (1976). Effects of dietary energy concentration on production of broiler chickens. Australian Journal of Agriculture and Animal Husbandry 16, 672-678.

Gous, R. M. \& Morris, T. R. (1985). Evaluation of a diet dilution technique for measuring the response of broiler chickens to increasing concentrations of lysine. British Poultry Science 26, 147-161.

Gregory, N. G., Lovell, R. D., Wood, J. D. \& Lister, D. (1977). Insulin-secreting ability in Pietrain and Large White pigs. Journal of Agricultural Science, Cambridge 89, 407-413.

Hammer, R. E., Pursel, V. G., Rexroad, C. E. Jr, Wall, R. J., Bolt, D. J., Ebert, K. M., Palmiter, R. D. \& Brinster, R. L. (1985). Production of transgenic rabbits, sheep and pigs by micro-injection. Nature 351, 680-683.

Hartsook, E. W. \& Hershberger, T. V. (1971). Interactions of major nutrients in whole-animal energy metabolism. Federation Proceedings 30, 1466-1473. 
Henderson, R., Whittemore, C. T., Ellis, M., Smith, W. C., Laird, R. \& Phillips, P. (1983). Comparative performance and body composition of control and selection line Large White pigs. 1. On a generous fixed feeding scale for a fixed time. Animal Production 36, 399-405.

Hentges, E. J., Marple, D. N., Roland, D. A. \& Pritchett, J. F. (1983). Growth and in vitro protein synthesis in two strains of chicks. Journal of Animal Science 57, 320-327.

Hodge, R. W. (1974). Efficiency of feed conversion and body composition of the preruminant lamb and the young pig. British Journal of Nutrition 32, 113-126.

Holmes, C. W., Carr, J. R. \& Pearson, G. (1980). Some aspects of the energy and nitrogen metabolism of boars, gilts and barrows given diets containing different concentrations of protein. Animal Production 31, $279-289$.

Jacob, R., Barrett, E., Plewe, G., Fagin, K., King, J. \& Sherwin, R. (1987). Insulin-like growth factor 1 inhibits proteolysis in the fasted rat. Proceedings of the 69 th meeting of the Endocrine Society. Journal of Endocrinology 120, Suppl., 223-227.

Johnson, R. J., Fairclough, R. J. \& Cahill, L. P. (1987). Temporal secretory patterns of growth hormone in young meat-type poultry. British Poultry Science 28, 103-111.

Johnson, R. J., Fairclough, R. J., Cahill, L. P. \& Parr, R. (1985). Temporal secretory patterns of growth hormone in the domestic fowl. Proceedings of the Endocrine Society of Australia 28, 106 Abstr.

Johnsson, I. D., Hart, I. C. \& Buttler-Hog, B. W. (1985). The effects of exogenous bovine growth hormone and bromocriptine on growth, body development, fleece weight and plasma concentrations of growth hormone, insulin and prolactin in female lambs. Animal Production 41, 207-218.

Leclercq, B. (1983). The influence of dietary protein content on the performance of genetically lean or fat growing chickens. British Poultry Science 24, 581-587.

Leciercq, B. \& Saadoun, A. (1982). Comparison of energy metabolism in genetically lean or fat lines of broilers. In Energy Metabolism of Farm Animals. European Association of Animal Production Publication no. 29, pp. 274-277 [A. Ekern and F. Sundstøl, editors]. Aas, Norway: Agricultural University of Norway.

Leung, F. C., Taylor, J. E., Wien, S. \& Van Iderstine, A. (1986). Purified chicken growth hormone (GH) and a human pancreatic GH-releasing hormone increase body weight gain in chickens. Endocrinology. 118, 1961-1965.

Lobley, G. E., Connell, A., Mollison, G., Brewer, A., Harris, C. J., Buchan, V. \& Galbraith, H. (1985). The effects of a combined implant of trenbolone acetate and oestradiol-17 $\beta$ on protein and energy metabolism in finishing beef steers. British Journal of Nutrition 54, 681-694.

Machlin, L. J. (1972). Effect of growth hormone on growth and carcass composition of the pig. Journal of Animal Science 35, 794-800.

Moody, W. G., Enser, M. B., Wood, J. D., Restall, D. J. \& Lister, D. (1978). Comparison of fat and muscle development in Pietrain and Large White pigs. Journal of Animal Science 46, 628-633.

National Research Council (1979). Nutrient Requirements of Domestic Animals no. 2, Nutrient Requirements of Swine. Washington, DC: National Academy of Sciences.

National Research Council (1984). Nutrient Requirements of Poultry. Washington, DC: National Academy Press.

Pesti, G. M. \& Smith, C. F. (1984). The response of growing broiler chickens to dietary contents of protein, energy and added fat. British Poultry Science 25, 127-138.

Savidge, J. A., Cole, D. J. A. \& Lewis, D. (1984). A study of dietary energy density and genotype interaction on the voluntary intake of pigs. Animal Production 38, 535 Abstr.

Schneider, W., Gaus, G., Michel, A., Susenbeth, A. \& Menke, K. H. (1982). Effect of level of feeding and body weight on partition of energy in growing pigs. In Energy Metabolism of Farm Animals. European Association of Animal Production Publication no. 29, pp. 225-228 [A. Ekern and F. Sundstøl, editors] Aas, Norway: Agricultural University of Norway.

Seamark, R. F. (1987). The potential of transgenic pigs and related technology for the pig industry. In Manipulating Pig Production, pp. 165-170 [J. L. Barnett, E. S. Batterham, G. M. Cronin, C. Hansen, P. H. Hemsworth, D. P. Hennessy, P. E. Hughes, N. E. Johnston and R. H. King, editors]. Victoria, Australia: V.I.P. Printing.

Searle, T. W. \& Griffiths, D. A. (1976). Differences in body composition between three breeds of sheep. Proceedings of the Australian Society of Animal Production 11, 57-60.

Siebritts, F. K. \& Kemm, E. H. (1982). Body composition and energetic efficiency of lean and obese pigs. In Energy Metabolism of Farm Animals. European Association of Animal Production Publication no. 29, pp. 237-241 [A. Ekern and F. Sundstøl, editors]. Aas, Norway: Agricultural University of Norway.

Siebritts, F. K., Kemm, E. H., Ras, M. N. \& Barnes, P. M. (1986). Protein deposition in pigs as influenced by sex, type and live mass. 1. The pattern and composition of protein deposition. South African Journal of Animal Science 16, 23-27.

Theriez, M., Tisser, M. \& Robelin, R. (1981). The chemical composition of the intensively fed lamb. Animal Production 32, 29-37.

Thompson, J. M., Atkins, K. D. \& Gilmour, A. R. (1979). Carcass characteristics of heavy weight crossbred lambs. II. Carcass composition and partitioning of fat. Australian Journal of Agricultural Research 30 , 1215-1221. 
Tullis, J. B. (1982). Protein growth in pigs. PhD Thesis, University of Edinburgh.

Wagner, T. E. (1985). The role of gene transfer in animal agriculture and biotechnology. Canadian Journal of Animal Science 65, 539-552.

Walker, D. M. \& Norton, B. W. (1971). The utilization of the metabolizable energy of diets of different protein content by the milk-fed lamb. Journal of Agricultural Science, Cambridge 77, 363-369.

Walton, P. E. \& Etherton, T. D. (1986). Stimulation of lipogenesis by insulin in swine adipose tissue: Antagonism by porcine growth hormone. Journal of Animal Science 62, 1584-1595.

Walton, P. E., Etherton, T. D. \& Chung, C. S. (1987). Exogenous pituitary and recombinant growth hormones induce insulin and insulin-like growth factor 1 resistance in pig adipose tissue. Domestic Animal Endocrinology 4, 183-190.

Walton, P. E., Etherton, T. D. \& Evock, C. M. (1986). Antagonism of insulin action in cultured pig adipose tissue by pituitary and recombinant porcine growth hormone: Potentiation by hydrocortisone. Endocrinology 118 , 2577-2581.

Webster, A. J. F., Lobley, G., Reeds, P. J. \& Pullar, J. D. (1978). Protein mass, protein synthesis and heat loss in the Zucker rat. Proceedings of the Nutrition Society 37, 21 A.

Webster, A. J. F., Smith, J. S. \& Mollison, G. S. (1977). Prediction of the energy requirements for growth in beef cattle. B. Body weight and heat production in Hereford \& British Fresian bulls and steers. Animal Production 24, 237-244.

Whittemore, C. T. (1986). An approach to pig growth modelling. Journal of Animal Science 63, 615-621.

Whittemore, C. T. \& Fawcett, R. H. (1976). Theoretical aspects of a flexible model to simulate protein and lipid growth in pigs. Animal Production 22, 87-96.

Williams, I. H. (1976). Nutrition of the young pig in relation to body composition. PhD Thesis, University of Melbourne.

Williams, W. D., Cromwell, G. L., Stahly, T. S. \& Overfield, L. (1984). The lysine requirement of the growing boar versus barrow. Journal of Animal Science 58, 657-665.

Wood, J. D., Enser, M. B. \& Restall, D. J. (1975). Fat cell size in Pietrain and Large white pigs. Journal of Agricultural Science, Cambridge 84, 221-225.

Yen, H. T., Cole, D. J. A. \& Lewis, D. (1986). Amino acid requirements of growing pigs. 8. The response of pigs from 50 to $90 \mathrm{~kg}$ live weight to dietary ideal protein. Animal Production 43, 155-166. 